\title{
AN INVESTIGATION INTO THE ETHICAL STANDARDS AND VALUES OF REGISTERED PROPERTY VALUERS IN SOUTH AFRICA
}

\author{
Brent Currin* \\ University of Johannesburg \\ brentcurrin@gmail.com \\ Tsebang Chuene* \\ University of Johannesburg \\ tsebangc@gmail.com
}

Received: October 2013

\author{
Nompilo Msibi** \\ University of Johannesburg \\ Nompilo.msibi@yahoo.com \\ Andre Kruger+ \\ University of Johannesburg \\ akruger@uj.ac.za
}

Accepted: June 2014

\begin{abstract}
Ethical issues and standards of property professions are being scrutinised. To date, no research has been carried out on the ethical standards in the property valuation profession in South Africa. This research compared the content of codes of ethics and professional conduct of the South African property valuation profession to international standards, and investigated the ethical standards and moral values held by registered valuers in South Africa. A self-administered survey, administered to 611 professional and professional associate valuers, was used. It measured five constructs of unethical behaviour layered into a survey adapted from Hoyt, Wright and Croft (2002). No statistically significant differences were found between different demographic factors in the ethical beliefs of South African valuers. A literature review comparing South Africa's codes of conduct with those in the United States of America, Australia and New Zealand showed that the standards of ethics and professional practice in South Africa are not in line with international standards. South African valuers appear to be ethical and resist external pressures which could lead to unethical behaviour.
\end{abstract}

Keywords

Code of conduct, ethics, property industry, registered valuers, regulatory body, SACPVP, South Africa.

*Mr B Currin is a postgraduate student in the Department of Finance and Investment Management, University of Johannesburg, South Africa.

**Ms N Msibi is a postgraduate student in the Department of Finance and Investment Management, University of Johannesburg, South Africa.

\#Mr T Chuene is a postgraduate student in the Department of Finance and Investment Management, University of Johannesburg, South Africa.

+ Mr A Kruger is a lecturer in the Department of Finance and Investment Management, University of Johannesburg, South Africa. 


\section{INTRODUCTION}

The global financial crisis of 2008, which resulted from a collapse in corporate governance regulation in general, and business ethics in particular, has given rise to an increased focus on business ethics around the world (Tseng, Duan, Tung \& Kung, 2010). Professionals who operate in the business world are frequently subjected to external pressures which may lead to acts of unethical behaviour (Hoyt, Wright \& Croft, 2002). One specific business practice where ethical regulation and standard setting is of paramount importance is the property industry, due to its worth of approximately 4.9 trillion rand in South Africa, according to Lovell (2012), and its major contribution to the country's Gross Domestic Product (GDP).

According to Andre and Velesquez (1987:3), 'ethics refers firstly to the standards of right and wrong that direct what humans ought to do, usually in terms of rights, obligations, benefits to society, fairness, or specific virtues, and secondly to the study and development of one's ethical standards.' 'Societies with higher levels of business ethics tend to be characterized by greater certainty of actions and lower costs of regulation and policing' (Bucar, Glas \& Hisrich, 2003:261). It is therefore essential to constantly examine one's own ethical standards to ensure that they are reasonable and acceptable and in accordance with the prescribed regulations.

Some countries are believed to demonstrate different levels of ethical standards compared to others, and in South Africa the ethical values of professionals operating in all sectors of the economy are somewhat unknown, but are believed to be of lower standards when compared to developed countries, and higher standards when compared to other African countries (Everett, 2010). According to Transparency International's Corruption Perception Index South Africa is ranked as the fifth least corrupt country out of 33 in the sub-Saharan African region and the $54^{\text {th }}$ least corrupt worldwide, out of 178 (Everett, 2010). With foreign investment being a major driving force of any economy, negative assumptions based on a country's level of ethical standards and regulation can have negative economic effects on all sectors of the economy; therefore, it is essential for a country's prosperity to avoid a situation where foreign investors look to invest elsewhere, due to a bad reputation. An undertaking to prove that South Africa is capable of demonstrating ethical standards and values within certain business practices is required.

Within the property industry, regulation is required to safeguard consumers from unethical behaviour, as there are countless opportunities for valuers to face ethical conflict on the job due to them being in a position of power with regard to confidential information (Hoyt et al., 2002). Since the earning potential of valuers depends upon the level of fees they generate, this may tempt valuers to alter their ethical beliefs and behave in an unethical manner in order to satisfy their clients and create valuable repeat business (Hoyt et al. 2002). Professional bodies exist within all major economies to ensure sufficient regulation of the property valuation industry through rules and development of codes of professional conduct in order to render the industry operational. In the South African context, the industry is governed by the South African Council for the Property Valuers Profession along with the South African Institute of Valuers (SAIV). South African valuers also have to be mindful of the Consumer Protection Act of 2008 and its implications.

In a study by Hoyt et al. (2002), it was found that differences in ethical beliefs exist among valuers in New Zealand, and these related to differences in age, valuation experience and levels of education. This study attempts to replicate the study done by Hoyt et al. (2002) in New Zealand within the context of property valuation in South Africa, as research pertaining to ethics 
in the property industry in South Africa is scarce, and no such research specifically detailing the ethics of property valuers could be found. Studies comparing South Africa's codes of ethics with those of other countries to ascertain if they are of the same standard could also not be sourced. Our study will help reduce this lack of knowledge, and add to the literature by determining the levels of ethical standards held by a sample of professionally qualified property valuers in South Africa. This study could potentially identify areas within the property industry that need further investigation in terms of ethical regulation.

The main purpose of this study is to investigate if South African property valuers are ethical and report ethics in their valuation reports.

This article has two aims or objectives:

- To investigate whether the standards of ethics and professional practice imposed on registered property valuers in South Africa compare to international standards, through a comparison of the content of the codes of professional conduct and ethics both locally and internationally.

- To investigate whether a sample of South African property valuers are ethical in their practices and take ethics into account by reporting ethical guidelines when preparing valuation reports.

\section{THEORETICAL FRAMEWORK}

Although codes of ethics for the property valuation profession have been developed by property valuation regulatory bodies, to which their members are expected to subscribe (Hoyt et al., 2002), little empirical research pertaining to ethics in real estate has been conducted. The available literature on ethics in the property industry includes a study by Sui Pheng and Tan (1995), which sets out to identify the ethical expectations of industry participants such as real estate agents in Singapore by surveying agents and clientele on their expectations. It draws the conclusion that the majority of agents are honest and displayed high levels of integrity in their conduct.

\subsection{Codes of Ethical Conduct}

In the South African property valuation industry, it is believed that standards contained within local codes of ethical conduct may be unaligned with those of international property valuation industries. We have therefore analysed the available literature pertaining to ethics and professional practice guidelines and have made a comparison between the South African Code of Ethical standards as set by the South African Council for Property Valuers Profession (SACPVP) and South African Institute of Valuers (SAIV) to those codes that regulate international property valuation industries such as the Appraisal Institute, International Valuation Standards Council (IVSC), Australian Property Institute (API), Property Institute of New Zealand (PINZ) and the New Zealand Institute of Valuers (NZIV). The Royal Institute of Chartered Surveyors (RICS) code of conduct could not be obtained for comparison. 


\subsection{Background}

The South African property valuation profession is governed by the statutory body known as the South African Council for the Property Valuers Profession, being one of six councils that operate in the Built Environment and were founded in 1983 and established by section 2 of the Property Valuers Profession Act, 2000 (South African Council for the Property Valuers Profession, 2000). The body is involved in a partnership with the state and with the valuation profession to promote high levels of education and training of practitioners in the property valuer's profession in order to facilitate the recognition of professionalism in the profession, both locally and internationally.

The South African Institute of Valuers was founded in 1909, and is dedicated to serving the public interest by advancing high standards for members of the appraisal profession through the setting and maintaining of high standards of professional proficiency, ethics and education (South African Institute of Valuers, 2009).

The Appraisal Institute, established in 1932, is a global membership association of professional real estate appraisers, with nearly 23,000 members in nearly 60 countries throughout the world (Appraisal Institute, 2003). Its mission is to advance professionalism and ethics, global standards, methodologies, and practices through the professional development of property economics worldwide (Appraisal Institute, 2003).

The International Valuation Standards Council is an independent, not for profit, private sector organisation incorporated in the US and with its headquarters in London that develops and promotes technical and ethical standards for its member to adhere to for valuations on which investors and others rely (International Valuation Standards Council, 2011).

The Australian Property Institute is the preferred Property Professional Membership association in Australia, and its primary role is to set and maintain the highest standards of professional practice, education, ethics and professional conduct for its members and the broader property profession (Australian Property Institute, 2007).

According to the Property Institute of New Zealand (2004), The Property Institute of New Zealand was formed in in the year 2000 and incorporated the membership of the New Zealand Institute of Valuers, the Institute of Plant \& Machinery Valuers, and the Property \& Land Economy Institute of New Zealand. Australia and New Zealand have both taken steps towards adopting International Valuation Standards, and both are strong supporters of and have played an active role in the work of International Valuation Standards Committee.

\subsection{Comparison of codes of professional conduct and ethics}

The code of professional conduct as set by the Appraisal Institute and the International Valuation Standards Council is seen as the standard to which other professional bodies operating in real estate valuation spheres should aspire, in terms of regulation and implementation of standards. These two codes of professional conduct are extremely comprehensive and provide extensive guidelines for members to adhere to, and are far more inclusive than the codes which govern the industry in South Africa, being the South African Council for the Property Valuers Profession's 'Code of Conduct for Registered Persons' and the South African Institute of Valuers 'Constitution'. 
'The purpose of the International Valuation Standards Council (IVSC) publishing a code of ethics was to promote principles of ethical conduct by professional valuers, however the IVSC has no remit to compel member organisations or others to adopt or follow any such code' (International Valuation Standards Council, 2011). 'The intention was to produce principles that it believed should be reflected in any professional code of conduct produced by bodies with regulatory powers or responsibilities for individual valuers or valuation firms, and encourage the convergence of individual codes to these principles' (International Valuation Standards Council, 2011). 'The Fundamental Principles contained within the code set out five principles of conduct that a professional valuer is expected to adhere to when providing valuation services' (International Valuation Standards Council, 2011), namely; a) integrity, b) objectivity, c) competence and due care, d) confidentiality and e) professional behaviour.

The code of professional ethics of the Appraisal Institute is made up of 'Canons', which prescribe what a member may and may not do and within each 'Canon' are sub-categories relating to specific 'Ethical Rules' which are to be adhered to.

An interesting comparison is also made between the codes of conduct of the Australian Property Institute and New Zealand Property Institute as against the South African Council of Property Valuers Profession and South African Institute of Valuers codes of conduct. Both organisations seem to be founded on high standards, emphasising personal integrity, honesty, dignity and fairness, which make up the pillars of the profession. Maintaining the integrity of both the professional and the profession is a recurring theme in all the countries that were studied.

In the API code of conduct, it is stipulated that member should include and justify any relevant hypothetical conditions and extraordinary limiting conditions. In the South African context, that aspect of a valuation report is not mentioned within the SAIV 'constitution' or SACPVP 'code of conduct for registered persons'. It is also evident that criminal acts are frowned upon in both nations' codes: the SACPVP retains the right to refuse to admit an individual who has a conviction, especially if the crime was if a fraudulent nature. API and PINZ rules state that a member who is convicted of an offence involving dishonesty is in breach of the Rules of Conduct.

The SACPVP, API, PINZ and the Appraisal Institute all prohibit a valuer from divulging confidential information contained in reports to any person other than the client. Members should not accept payment or favours from any party other than their client or his agent if it may affect the relationship with the client. All the codes of professional conduct indicate that registered persons must be loyal to their clients, and must discharge their duties in an expeditious manner. Members must also act with the strictest objectivity and impartiality.

An analysis of the major similarities and differences between the codes that govern South Africa as against the codes that govern Australia resulted in the following recommendations.

\section{Recommendations}

After analysis of the various codes, it can be concluded that more emphasis should be placed on the physical inspection of property performed by valuers, which is evident in the New Zealand and Australian codes of professional conduct but not mentioned in any of the South African codes. It is recommended that we practise compulsory physical inspections for all valuations in South Africa and eliminate desktop valuation as used by governmental bodies in their mass valuation method when compiling the valuation role for various municipalities. It is also recommended that the SACPVP adopts the copyright rule/law to protect members' intellectual property, as this will also encourage South African Valuers to be original in executing their work and to avoid replicating the work of other valuers. 
In general, it would be beneficial for the South African codes of professional conduct to be more specific on certain aspects, and thus become more detailed and comprehensive, so as to fall in line with the code of professional conduct as set by the Appraisal Institute and International Valuation Standards Council.

\section{RESEARCH METHODOLOGY}

\subsection{Research objective}

This research was descriptive in nature. A self-administered structured questionnaire was used in this study to obtain primary data on the ethics of South African property valuers, and the data collected comprised ordinal data. The methodology and design replicated a previous study conducted by Hoyt et al. with their permission (Hoyt et al., 2002). The five constructs used by Harris and adapted by Hoyt have been tested and reported upon in previous studies (Harris, 1990; Harris, 1991; O’Clock \& Okleshen, 1993; Okleshen \& Hoyt, 1996)

We compared the following demographic factors: 1) Gender, 2) Age Range, 3) Level of Academic Qualification/ Education and 4) Level of Valuation Experience, to determine whether differences in these factors have an impact on the ethical beliefs of valuers.

\subsection{Unit of analysis}

The unit of analysis was the individual professional property valuers located within major economic regions within South Africa.

\subsection{Population}

The population for this study was 611 'professional' and 'professional associate' valuers registered with the South African Council of Property Valuers Profession. 'Candidate' valuers were excluded, as they are still learning and gaining experience in the industry. The targeted individuals were specifically located in the major economic regions of South Africa, namely Johannesburg, Pretoria, Cape Town, Durban and Bloemfontein. The reason behind the selection of a sample population of only 611 valuers located within the abovementioned regions was due to the time constraints involved in compiling a database of all registered valuers in the Republic of South Africa.

\subsection{Sampling and data collection}

The sampling frame was all the registered valuers for whom a valid email address was available. With the aid of the SACPVP portal and member database, we were able to distribute the questionnaire by e-mail on 27 September 2012. Various techniques were used to encourage responses. These techniques included the use of a cover letter which accompanied the questionnaire; it drew the respondent's attention to the purpose and importance of the study, emphasised the respondent's confidentiality and included instructions on how to send back the completed questionnaire for those unfamiliar with e-mail. Another technique included the use of follow-up reminders to respondents to complete the survey before the final submission date.

The distribution managed to produce a response of 84 usable questionnaires, constituting a response rate of $13.75 \%$. This is considerably lower than those achieved by Hoyt et al. (2002), 
where a rate of $41.7 \%$ was recorded. The response rate could be low due to the length and complexity of the questionnaire used in the study, or, alternatively, evidence of a 'lack of response' culture prevalent in South Africa. No incentive was offered as motivation to complete the survey to any respondent.

\subsection{Demographics}

Of those responding:

- 66 of the respondents (81\%) were identified as male and 16 (19\%) as female.

- The ages of respondents were grouped, with the largest age group representing persons aged 50 to 59 years (33.3\%), and this was followed by 30 to 39 years (21.4\%).

- $79 \%$ of the respondents comprised persons of 'white' ethnicity, $11 \%$ being of 'black' ethnicity, while other race groups such as 'coloured', 'Indian' and 'international' making up the remaining $10 \%$.

- The majority of respondents have a tertiary qualification - either an approved undergraduate diploma (53.6\%) or bachelor's degree (23.81\%) - with the undergraduate diploma being the minimum educational requirement for registration as a valuer in South Africa. 18 respondents (21\%) hold a higher postgraduate degree.

- Due to the majority of respondents being over 50 years of age, $44.7 \%$ have had 20 years or more experience as valuers in the industry, $25.9 \%$ have 6 to 10 years, and $25.9 \%$ had levels of experience of between 11 and 20 years.

- $56 \%$ of respondents identified themselves as registered 'professional valuer's' and $44 \%$ as 'professional associate valuers'.

\subsection{Data measurement}

Use was made of a 5-point and 3-point Likert-scale respectively, requiring respondents to indicate their level of agreement or lack thereof to the ethical behaviour described in each scenario in Part B and to the questions regarding ethics in Part C. The questions (1-10) in Part B of the survey were adapted, with written permission, from a survey conducted by Hoyt et al. (2002) detailing the ethical values of registered valuers in New Zealand. The interpretation of the results obtained in our survey is also done in the same manner as Hoyt et al. (2002).

Each of the constructs tested within Part B of the questionnaire (deceit, coercive power, influence dealing, fraud and self-interest) makes use of two questions associated with property valuation, estate agency and financing. The property industry is appropriately interconnected for participants to be knowledgeable in the basics of each of the three areas of specialisation (valuation, estate agency and financing) and therefore each should have a level of understanding of the concepts addressed in the questionnaire (Hoyt et al., 2002).

The two questions for each construct in Part B of the questionnaire are identified and located in this manner: deceit as questions 1 and 7 ; coercive power as questions 2 and 5 ; influence dealing as questions 4 and 10; fraud as questions 6 and 9 ; and self-interest as 3 and 8 .

The responses were then encoded by assigning a value to each response on each variable as $1=$ Strongly Agree, 2 = Agree, 3 = Neutral, $4=$ Disagree and 5 = Strongly Disagree. 
A score of 1 indicates high levels of unethicalness, while a score of 5 is indicative of high levels of ethics. The responses to the two questions for each construct are summed, resulting in a possible range from 2 (highest agreement) to 10 (highest disagreement). On the range of 2 to 10 , the mid-point or point of indifference is 6.00 (Hoyt et al., 2002).

Authorisation for the use and adaptation of the questionnaire used by Hoyt et al. (2002) to be used for this study was obtained from Hoyt et al. (2002). Adaptation took the form of changes to the wording of the questions within Part B of the questionnaire to ensure applicability to the South African context.

\section{DATA ANALYSIS}

We used the following descriptive statistics to analyse the data:

Counts: 'Being the number of responses in each category for each variable' (Walt, 2010:27).

Mean: The mean was calculated by dividing the sum of the responses by the number of responses. 'This statistic could only be interpreted as a measure of central tendency by providing an indication of a "centre of gravity" for the responses' (Walt, 2010:27). In the case of this study the "centre of gravity" or point of indifference is 6.00 .

Standard Deviation $(\sigma)$ : 'The standard deviation could only be interpreted a relative measure of variance in responses between the different constructs' (Walt, 2010:27).

We used a 2-sample, 2-tailed, $T$-test, with significance level of $5 \%$, to assess whether gender is a significant predictor of ethical beliefs. We used a single factor Analysis of Variance (ANOVA) to assess whether age, level of academic qualification, level of valuation experience were significant predictors of ethical beliefs.

\section{RESULTS}

All five constructs were supported by high levels of disagreement (TABLE 1).

TABLE 1: Mean scores and standard deviations of five constructs pertaining to ethical values

\begin{tabular}{lcc}
\hline Construct & Mean & Standard Deviation \\
\hline Deceit & 7.95 & 1.66 \\
Fraud & 9.05 & 1.73 \\
Coercion & 8.15 & 1.46 \\
Self-Interest & 7.20 & 1.68 \\
Influence Dealing & 7.77 & 1.67 \\
\hline
\end{tabular}

Source: Authors' analysis

An important observation is that the highest level of disagreement is in the area of fraud (9.05); most of the respondents are therefore opposed to fraudulent behaviour (TABLE 1 ). Of concern is that the lowest level of disagreement towards about issues in the area of self-interest (7.20), as 
this value is closer to the midpoint (neutral $=6$ ) than the mean values for the other constructs. Therefore respondents do not feel as opposed to acts of self-interest as to other constructs (TABLE 1).

TABLE 2: Mean scores and standard deviations of five constructs by gender

\begin{tabular}{|c|c|c|}
\hline \multicolumn{3}{|c|}{ GENDER } \\
\hline Construct & Male & Female \\
\hline Deceit & 7.98 & 7.88 \\
\hline$(P=0.822348)$ & $(1.71)$ & (1.31) \\
\hline Fraud & 9.14 & 8.75 \\
\hline$(P=0.563)$ & $(1.56)$ & $(2.38)$ \\
\hline Coercion & 8.24 & 8.13 \\
\hline$(P=0.918)$ & $(1.45)$ & $(1.20)$ \\
\hline Self-Interest & 7.27 & 7.19 \\
\hline$(P=0.969)$ & $(1.68)$ & $(1.68)$ \\
\hline Influence Dealing & 7.64 & 8.25 \\
\hline$(P=0.116)$ & $(1.76)$ & $(1.18)$ \\
\hline
\end{tabular}

Source: Authors' analysis

* 2-sample, 2 tailed, t-test, statistically significant @ 5\% level, standard deviation in parentheses

There was no statistically significant difference between the female and male valuers in terms of all five constructs; therefore female valuers as a group are no more concerned than their male counterparts on matters concerning all of the five constructs (TABLE 2).

TABL 3 shows that within the construct of self-interest, the mean values for valuers ages 20 to 29 were close to neutral (6.17). However, there was no statistically significant difference between valuers in terms of age for all five constructs.

TABLE 4 shows that within the construct of fraud the highest levels of disagreement are among those with an honours degree. Of concern is the fact that neutral opinions were given by persons with a 'doctoral' degree towards the construct of influence dealing (6.00). There was no statistically significant difference between valuers based on levels of education in terms of all five constructs. 
TABLE 3: Mean scores and standard deviations of five constructs by age

\begin{tabular}{|c|c|c|c|c|c|c|}
\hline Construct & $\begin{array}{c}20 \text { to } 29 \\
\text { years }\end{array}$ & $\begin{array}{c}30 \text { to } 39 \\
\text { years }\end{array}$ & $\begin{array}{l}\text { AGE } \\
40 \text { to } 49 \\
\text { years }\end{array}$ & $\begin{array}{c}50 \text { to } 59 \\
\text { years }\end{array}$ & $\begin{array}{l}60 \text { to } 69 \\
\text { years }\end{array}$ & $\begin{array}{c}70 \text { years and } \\
\text { above }\end{array}$ \\
\hline $\begin{array}{l}\text { Deceit } \\
(F=0.330301) \\
(P=0.856774)\end{array}$ & $\begin{array}{c}7.83 \\
(0.98)\end{array}$ & $\begin{array}{c}8.06 \\
(1.26)\end{array}$ & $\begin{array}{c}8.25 \\
(1.09)\end{array}$ & $\begin{array}{c}7.68 \\
(1.94)\end{array}$ & $\begin{array}{c}8.07 \\
(2.27)\end{array}$ & $\begin{array}{c}8.00 \\
(1.63)\end{array}$ \\
\hline $\begin{array}{l}\text { Fraud } \\
(F=0.262818) \\
(P=0.932026)\end{array}$ & $\begin{array}{c}9.67 \\
(0.52)\end{array}$ & $\begin{array}{c}8.94 \\
(1.63)\end{array}$ & $\begin{array}{c}9.00 \\
(2.22)\end{array}$ & $\begin{array}{c}8.89 \\
(1.89)\end{array}$ & $\begin{array}{c}9.14 \\
(1.66)\end{array}$ & $\begin{array}{c}9.5 \\
(1.00)\end{array}$ \\
\hline $\begin{array}{l}\text { Coercion } \\
(F=0.575185) \\
(P=0.718799)\end{array}$ & $\begin{array}{c}7.33 \\
(0.52)\end{array}$ & $\begin{array}{c}8.22 \\
(1.35)\end{array}$ & $\begin{array}{c}8.29 \\
(1.33)\end{array}$ & $\begin{array}{c}8.04 \\
(1.62)\end{array}$ & $\begin{array}{c}8.43 \\
(1.74)\end{array}$ & $\begin{array}{c}8.5 \\
(1.29)\end{array}$ \\
\hline $\begin{array}{l}\text { Self-Interest } \\
\begin{array}{l}(F=1.366087) \\
(P=0.253795)\end{array}\end{array}$ & $\begin{array}{c}6.17 \\
(1.47)\end{array}$ & $\begin{array}{c}6.89 \\
(1.78)\end{array}$ & $\begin{array}{c}7.93 \\
(1.44)\end{array}$ & $\begin{array}{c}7.14 \\
(1.76)\end{array}$ & $\begin{array}{c}7.29 \\
(1.77)\end{array}$ & $\begin{array}{c}7.75 \\
(0.96)\end{array}$ \\
\hline $\begin{array}{l}\text { Influence } \\
\text { Dealing } \\
(F=0.868821) \\
(P=0.486752)\end{array}$ & $\begin{array}{c}8.17 \\
(0.41)\end{array}$ & $\begin{array}{c}8.00 \\
(1.64)\end{array}$ & $\begin{array}{c}7.71 \\
(1.14)\end{array}$ & $\begin{array}{c}7.96 \\
(1.62)\end{array}$ & $\begin{array}{c}7.07 \\
(2.43)\end{array}$ & $\begin{array}{c}7.5 \\
(1.91)\end{array}$ \\
\hline
\end{tabular}

Source: Authors' analysis

* ANOVA statistically significant @ 0.05 level, standard deviation in parentheses.

TABLE 5 shows that within the construct of fraud, the highest levels of disagreement are among those with 1 to 5 years' experience. Valuers with 11 to 15 years' experience have the highest levels of disagreement concerning practices of deceit, self-interest and influence dealing. There was no statistically significant difference between valuers based on levels of experience in terms of all five constructs. 
AN INVESTIGATION INTO THE ETHICAL STANDARDS AND VALUES OF REGISTERED PROPERTY VALUERS

TABLE 4: Mean scores and standard deviations of the five constructs by level of academic qualification

\begin{tabular}{|c|c|c|c|c|c|}
\hline \multicolumn{6}{|c|}{ LEVEL OF ACADEMIC QUALIFICATION/ EDUCATION } \\
\hline Construct & $\begin{array}{l}\text { National } \\
\text { Diploma }\end{array}$ & $\begin{array}{c}\text { Bachelor's } \\
\text { Degree }\end{array}$ & $\begin{array}{c}\text { Honours } \\
\text { Degree }\end{array}$ & $\begin{array}{c}\text { Master's } \\
\text { Degree }\end{array}$ & $\begin{array}{c}\text { Doctorate } \\
\text { Degree }\end{array}$ \\
\hline $\begin{array}{l}\text { Deceit } \\
(F=1.759303) \\
(P=0.145551)\end{array}$ & $\begin{array}{c}8.24 \\
(1.57)\end{array}$ & $\begin{array}{c}7.38 \\
(2.01)\end{array}$ & $\begin{array}{c}8.11 \\
(1.27)\end{array}$ & $\begin{array}{c}8.17 \\
(1.17)\end{array}$ & $\begin{array}{c}6.33 \\
(1.53)\end{array}$ \\
\hline $\begin{array}{l}\text { Fraud } \\
(F=0.251512) \\
(P=0.907919)\end{array}$ & $\begin{array}{c}9.00 \\
(1.87)\end{array}$ & $\begin{array}{c}9.00 \\
(1.84)\end{array}$ & $\begin{array}{c}9.56 \\
(0.73)\end{array}$ & $\begin{array}{c}8.83 \\
(2.04)\end{array}$ & $\begin{array}{c}8.67 \\
(1.15)\end{array}$ \\
\hline $\begin{array}{l}\text { Coercion } \\
(F=0.644747) \\
(P=0.632235)\end{array}$ & $\begin{array}{c}8.11 \\
(1.60)\end{array}$ & $\begin{array}{c}7.90 \\
(1.41)\end{array}$ & $\begin{array}{c}8.56 \\
(1.24)\end{array}$ & $\begin{array}{c}8.83 \\
(0.75)\end{array}$ & $\begin{array}{c}8.00 \\
(1.73)\end{array}$ \\
\hline $\begin{array}{l}\text { Self-Interest } \\
(F=1.085399) \\
(P=0.369606)\end{array}$ & $\begin{array}{c}7.40 \\
(1.91)\end{array}$ & $\begin{array}{c}6.60 \\
(1.43)\end{array}$ & $\begin{array}{c}7.33 \\
(1.58)\end{array}$ & $\begin{array}{c}7.83 \\
(0.75)\end{array}$ & $\begin{array}{c}6.67 \\
(0.58)\end{array}$ \\
\hline $\begin{array}{l}\text { Influence } \\
\text { Dealing } \\
(F=0.902402) \\
(P=0.466812)\end{array}$ & $\begin{array}{c}7.87 \\
(1.71)\end{array}$ & $\begin{array}{c}7.70 \\
(1.81)\end{array}$ & $\begin{array}{c}7.78 \\
(1.56)\end{array}$ & $\begin{array}{c}8.00 \\
(1.41)\end{array}$ & $\begin{array}{c}6.00 \\
(0.00)\end{array}$ \\
\hline
\end{tabular}

Source: Authors' analysis

*ANOVA statistically significant @ 0.05 level, standard deviation in parentheses. 
TABLE 5: Mean scores and standard deviations of the five constructs by level of valuation experience

\begin{tabular}{|c|c|c|c|c|c|}
\hline \multicolumn{6}{|c|}{ LEVEL OF VALUATION EXPERIENCE } \\
\hline Construct & $\begin{array}{l}1 \text { to } 5 \\
\text { years }\end{array}$ & $\begin{array}{l}6 \text { to } 10 \\
\text { years }\end{array}$ & $\begin{array}{l}11 \text { to } 15 \\
\text { years }\end{array}$ & $\begin{array}{l}16 \text { to } 20 \\
\text { years }\end{array}$ & $\begin{array}{c}\text { More than } 20 \\
\text { years }\end{array}$ \\
\hline $\begin{array}{l}\text { Deceit } \\
(F=1.364638) \\
(P=0.253763)\end{array}$ & $\begin{array}{c}8.50 \\
(0.71)\end{array}$ & $\begin{array}{c}7.45 \\
(1.22)\end{array}$ & $\begin{array}{c}8.82 \\
(0.87)\end{array}$ & $\begin{array}{c}7.77 \\
(1.60)\end{array}$ & $\begin{array}{c}8.00 \\
(2.00)\end{array}$ \\
\hline $\begin{array}{l}\text { Fraud } \\
(F=0.733736) \\
(P=0.571661)\end{array}$ & $\begin{array}{l}10.00 \\
(0.00)\end{array}$ & $\begin{array}{c}8.82 \\
(2.02)\end{array}$ & $\begin{array}{c}9.36 \\
(1.03)\end{array}$ & $\begin{array}{c}8.45 \\
(1.92)\end{array}$ & $\begin{array}{c}9.21 \\
(1.71)\end{array}$ \\
\hline $\begin{array}{l}\text { Coercion } \\
(F=2.109388) \\
(P=0.087397)\end{array}$ & $\begin{array}{c}8.00 \\
(1.41)\end{array}$ & $\begin{array}{c}8.14 \\
(1.13)\end{array}$ & $\begin{array}{c}8.09 \\
(0.94)\end{array}$ & $\begin{array}{c}7.09 \\
(1.92)\end{array}$ & $\begin{array}{c}8.50 \\
(1.52)\end{array}$ \\
\hline $\begin{array}{l}\text { Self-Interest } \\
(F=1.310025) \\
(P=0.273516)\end{array}$ & $\begin{array}{c}6.00 \\
(2.83)\end{array}$ & $\begin{array}{c}6.77 \\
(1.77)\end{array}$ & $\begin{array}{c}8.00 \\
(1.48)\end{array}$ & $\begin{array}{c}7.45 \\
(1.86)\end{array}$ & $\begin{array}{c}7.21 \\
(1.56)\end{array}$ \\
\hline $\begin{array}{l}\text { Influence } \\
\text { Dealing } \\
(F=1.04355) \\
(P=0.390192)\end{array}$ & $\begin{array}{c}7.50 \\
(2.12)\end{array}$ & $\begin{array}{c}8.14 \\
(0.89)\end{array}$ & $\begin{array}{c}8.27 \\
(1.62)\end{array}$ & $\begin{array}{c}7.09 \\
(1.87)\end{array}$ & $\begin{array}{c}7.63 \\
(1.94)\end{array}$ \\
\hline
\end{tabular}

Source: Authors' analysis

*ANOVA statistically significant @ 0.05 level, standard deviation in parentheses.

It was discovered that a select few of the respondents only indicated 'strongly disagree' to all the questions in Part B of the questionnaire, and this could have been for one of two reasons:

- The respondent is being honest and 'strongly disagrees' with each situation, making him entirely ethical.

- The respondent has observed that in order to be portrayed as ethical he would need to 'strongly disagree' with each question and regardless of his actual opinion on each situation, he has indicated strong levels of disagreement anyway. This is a form of response bias or more specifically 'social desirability bias', as these respondents have consciously answered the questions in Part B of the questionnaire with a predetermined attitude, thus misrepresenting the truth (Zikmund, Babib \& Carr, 2010:193).

Based on the abovementioned likelihood of responder bias taking place, Part B of the questionnaire is therefore not necessarily an accurate representation of the ethical values of property valuers in South Africa, but none the less is still a fairly good gauge as to the ethical standards of valuers who responded to the questionnaire.

The following results pertain to Part $\mathrm{C}$ of the questionnaire: 


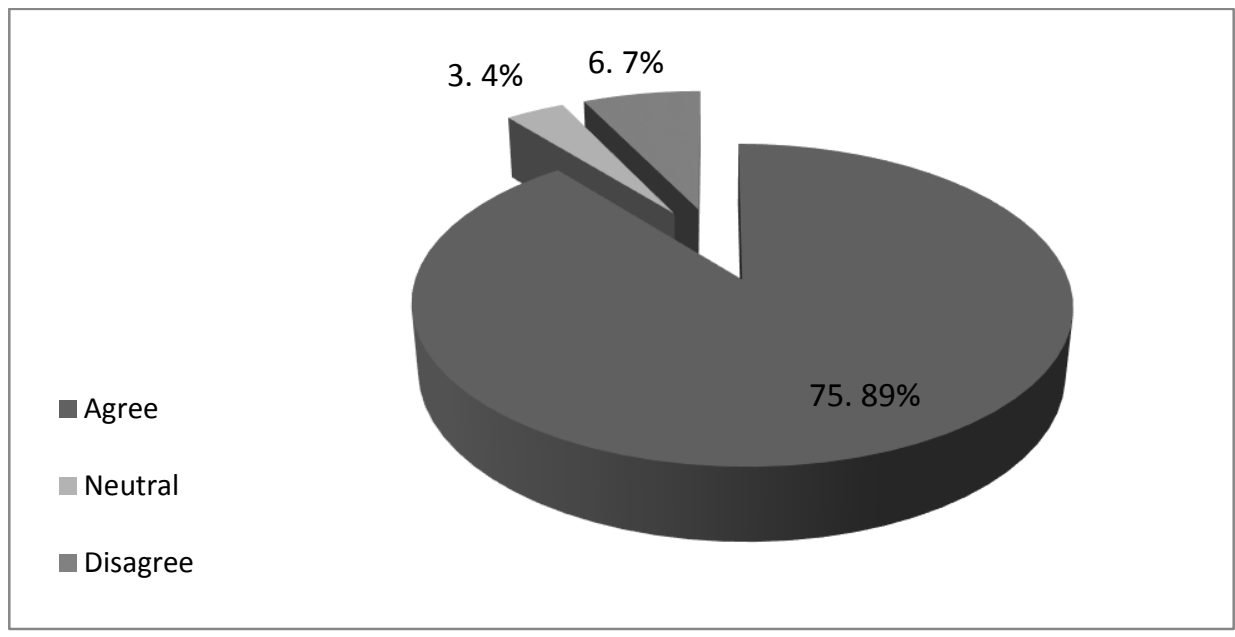

FIGURE 1: Percentage of responses to the statement " $E$ thics and ethical standards are considered an important consideration made by valuers when providing valuation services for clients."

Source: $\quad$ Authors'analysis

FIGURE 1 shows that the vast majority of respondents feel that ethics are an important consideration to be made by valuers when providing valuation services ( $75.89 \%$ agreed). Of concern is the fact that $6.7 \%$ of the respondents feel that ethics are not an important consideration to be made by valuers, which suggests that they may not take ethics into account.

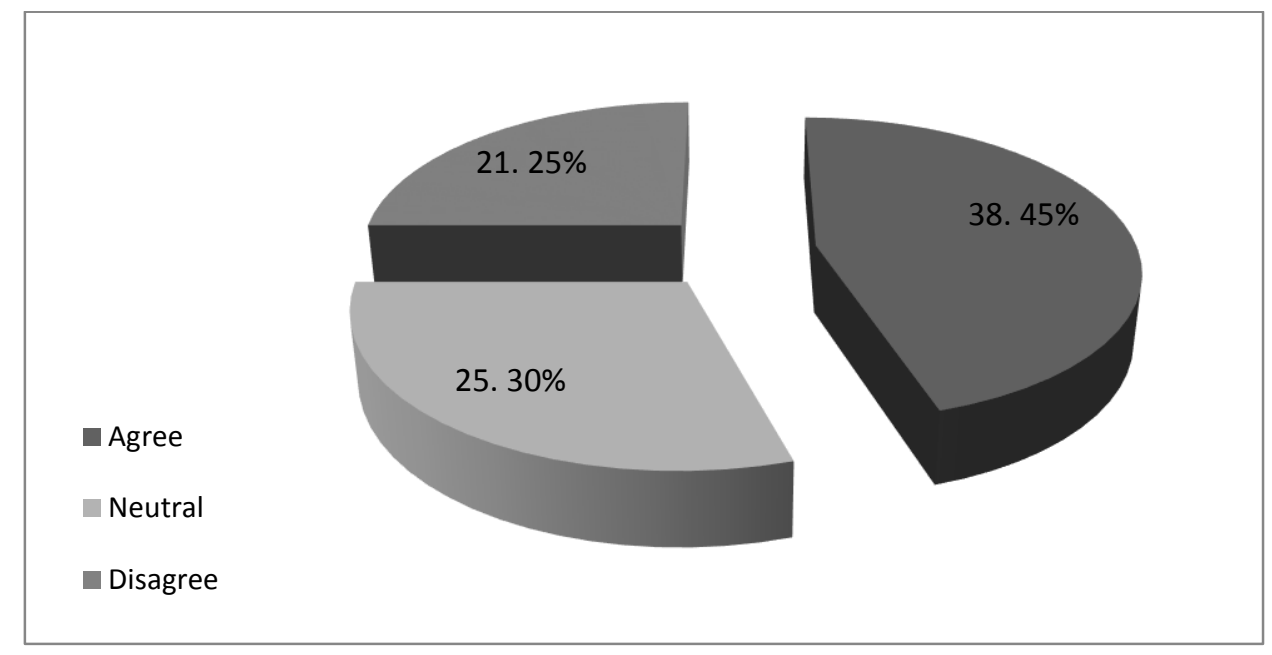

FIGURE 2: Percentage of responses to the statement "Registered valuers within South Africa behave in a manner that is in accordance with ethical standards as set by the South African Council of Property Valuers Profession."

Source: $\quad$ Authors'analysis 
FIGURE 2 indicates that the majority of the respondents believe that registered valuers do behave in accordance with the ethical standards set by the SACPVP; however, this value was small (38.45\% agreed). One also notices that $21.25 \%$ of the respondents believe that registered valuers do not behave in accordance with the standards as set by the SACPVP, which suggests that acts of unethical behaviour may have been observed by peer valuers or colleagues

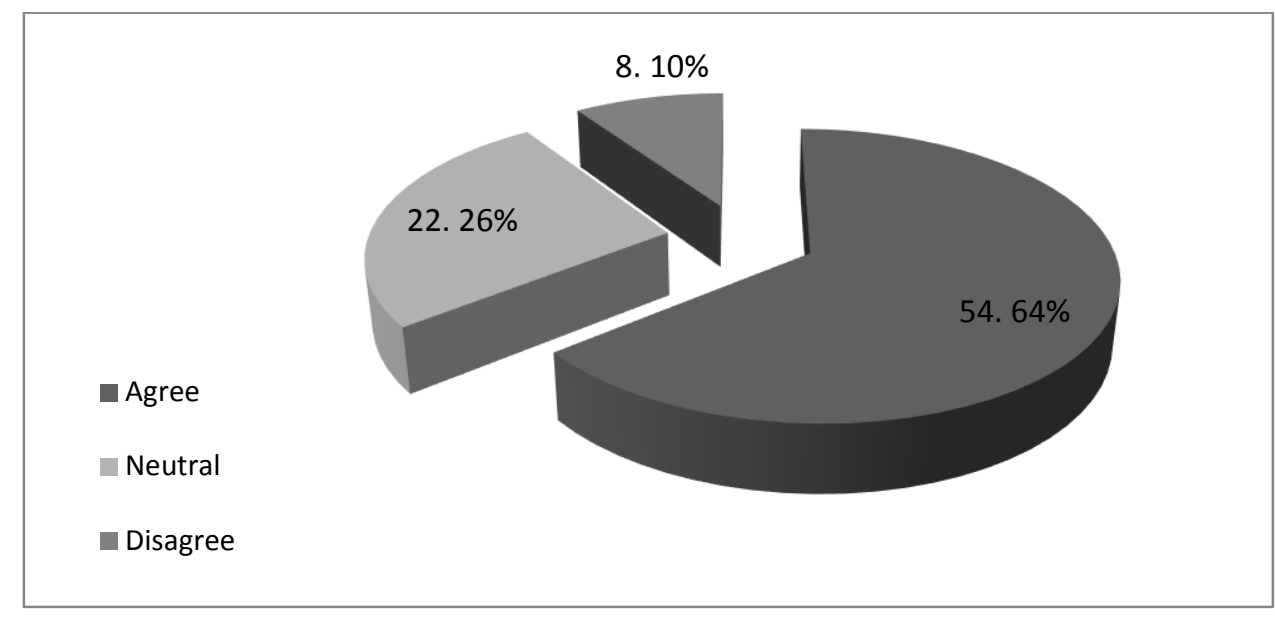

FIGURE 3: Percentage of responses to the statement "The inclusion of limiting conditions and assumptions is considered a form of ethical disclosure made by property valuers in their valuation reports."

Source: Authors'analysis

FIGURE 3 indicates that the majority of the respondents believe that 'limiting conditions and assumptions' are a form of ethical disclosure in their reports for clients ( $54.64 \%$ agreed). A small percentage believes that it is not a form of ethical disclosure, but rather perhaps, a statement describing the conditions on which the report is based. 


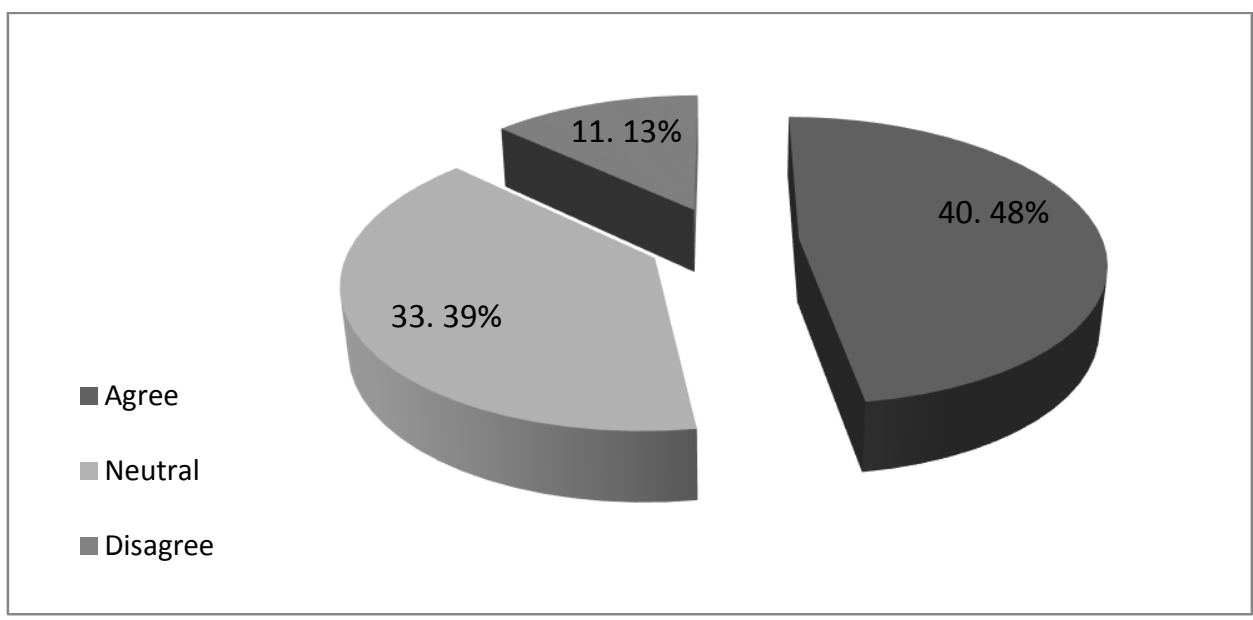

FIGURE 4: Percentage of responses to the statement "Valuation reports should include a section specifically detailing the ethical standards practiced by valuers in their valuation assignments."

Source: Authors' analysis

FIGURE 4 indicates that the majority of respondents believe that reports should contain a section specifically detailing the ethical considerations performed by the valuer $(40.48 \%$ agreed). A large percentage of the respondents also feel 'neutral' towards whether valuers need to specifically include a section on ethics (33.39\%), but rather perhaps that they should behave ethically instead of having to report on ethics specifically.

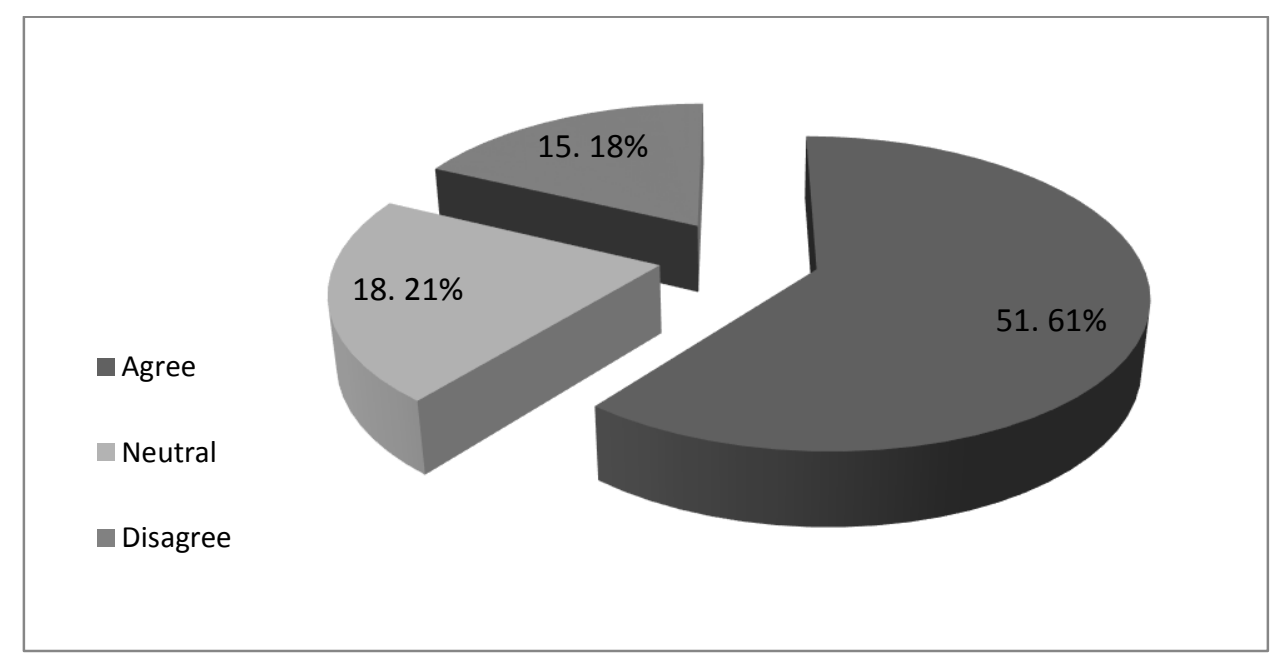

FIGURE 5: Percentage of responses to the statement "Ethics is specifically included in all valuation reports prepared in your personal capacity or as an agent for your organisation."

Source: Authors' analysis 
FIGURE 5 indicates that the majority of respondents specifically include ethics in their valuation reports $(51.61 \%$ agreed). A small percentage indicated that they do not include ethics in the valuation reports, possibly due to the fact that they practise ethical behaviour and do not feel the need to include a section on ethics.

\section{CONCLUSION}

This study aimed to investigate whether the standards of ethics and professional practice in South Africa compare to international standards, through a comparison on the content of the codes of professional conduct and ethics, as well as whether South African valuers are ethical in their practices as valuers and take ethics into account by reporting ethical guidelines when preparing valuation reports.

Of the five ethical constructs (deceit, coercive power, influence dealing, fraud and selfinterest) observed in the responses of registered valuers to Part B of the questionnaire, the greatest disagreement concerned scenarios that constituted fraudulent behaviours. The levels of disagreement on situations were then followed by coercion and deceitful practice. Of concern are the lower levels of disagreement on situations involving self-interest and influence dealing, which were to be expected as these findings are the same as those found in earlier studies by Harris (1990), Hoyt (1998) and Hoyt et al. (2002). As stated by Hoyt (1998), 'the acceptance of these types of activities may reflect the independence generally associated with the vocation'. No statistically significant differences existed when the mean differences between various demographic factors were evaluated.

The finding that male valuers are no more tolerant of unethical behaviour than their female counterparts in South Africa is identical to the finding by Hoyt et al. (2002), who found that no statistical difference existed between the female and male valuers in New Zealand. The findings are however contrary to the studies of Hoyt (1998) and Harris (1990), which both found a difference for the self-interest construct, with Hoyt (1998) finding additional differences for the coercion, fraud and influence dealing constructs for valuers in the state of Nevada. Gender, age, levels of education and experience were identified as not being statistically significant variables for differences in the ethical beliefs of South African valuers. The finding of Hoyt et al. (2002) that 'the older and more experienced a respondent, the less tolerant he/she will be to an unethical scenario' was not evident in this study's results. Therefore older and more experienced valuers are just as likely to act unethically as younger, less experienced valuers.

As part of our findings in relation to part C of the questionnaire, although $40.48 \%$ of the respondents feel it unnecessary to specifically include ethical standards practised by them in their valuation reports, $51.61 \%$ do appear to be taking ethics in account and report the ethical guidelines practised by them when preparing valuation reports for their clients.

Based on the literature review done in this study, we can conclude that the standards of ethics and professional practice imposed on registered property valuers in South Africa do not compare and are not up to the standards of those in America (Appraisal Institute \& International Valuation Standards Council), but are more comparable and fairly similar to those in Australia and New Zealand (API \& NZIP). Therefore regulatory bodies operating in South Africa should consider revising their codes of ethics and professional conduct so as to impose stricter regulation and elaborate on practices which may be unclear in the codes. 
We can also conclude that although South African standards of ethics and professional practice are inadequate when compared to international standards, South African valuers still appear to be ethical and do not to give in to external pressures which would lead to acts of unethical behaviour. This conclusion is due to the general high levels of disagreement for all five constructs, suggesting that property valuers in South Africa are ethical in their business practices, as the questionnaire was designed in such a way that in order to be ethical the respondent should disagree with the scenario proposed.

The study has the potential to be reproduced in other sectors of the property industry in South Africa, such as within the estate agency or quantity surveying fields. There are also further opportunities to undertake cross-cultural comparisons within specific sectors of the property industry to other international countries. According to Hoyt et al. (2002), various local or regional factors may impact upon the ethical beliefs of registered valuers in diverse ways, and therefore by being aware of and resolving any differences we can assist in building relationships of trust between those who use valuers and other professionals operating within the property and financial industries.

Foreign investment and foreign investors who wish to make capital investments in the South African property industry can be assured that when dealing with property valuers locally the chance of these professionals acting unethically is limited and the public at large should be encouraged to do business with these individuals. The findings of this study prove that the property industry, and specifically the valuation profession, in South Africa is an ethical one, capable of not giving in to the temptation of unethical behaviour for personal gain.

\section{LIST OF REFERENCES}

Andre, C. \& Velesquez, M. (1987). What is ethics? Issues in Ethics, 1, Fall 1987.

Appraisal Institute (2003). Code of Professional Ethics. [Online] Available: http://www.appraisalinstitute.org/about/ (Accessed l October 2012).

Australian Property Institute (2007). Code of Professional Conduct. [Online] Available: http://www.api.org.au/menuitem/about-api/who-is-the-api (Accessed 1 October 2012).

Bucar, B., Glas, M. \& Hisrich, R.D. (2003). Ethics and entrepreneurs. Journal of Business Venturing, 18(2), pp. 261-281.

Everett, S. (2010). Transparency International's corruption perceptions index 2010. [0nline] Available: http://www.transparency.org (Accessed 24 0ctober 2012).

Harris, J.R. (1990). Ethical values of individuals at different levels of the organizational hierarchy of a single firm. Journal of Business Ethics, 9, pp. 741-750.

Harris, J.R. (1991). Ethical values and decision processes of business and non-business students; a four group study. Journal of Lega/ Studies Education, 9, pp. 216-230.

Hoyt, R.W., Wright, M.J. \& Croft, C.S. (2002). The ethical values of registered valuers in New Zealand. Conference proceedings of the Seventh Pacific-Rim Real Estate Society Conference held in Canterbury.

International Valuation Standards Council (2011). Code of Ethical Principles for Professional Valuers. [Online] Available: http://www.ivsc.org (Accessed 15 November 2012) 
Lovell, J., (2012). New research values South Africa's property sector at R4.9 trillion. [Online] Available: http://www.propertycharter.co.za/news_article (Accessed 28 0ctober 2012).

O'Clock, P. \& Okleshen, M. (1993). A comparison of the ethical perceptions of business and engineering majors. Journal of Business Ethics, 12, pp. 677-687.

Okleshen, M. \& Hoyt, R. (1996). A cross cultural comparison of ethical perspectives and decision approaches of business students: United States of America versus New Zealand. Journal of Business Ethics, 15, pp. 537-549.

Property Institute of New Zealand (2004). Code of Ethics and Rules of Conduct. [Online] Available: http://www.property.org.nz/Category (Accessed 250 ctober 2012).

Republic of South Africa (RSA). (2000). Section 2 of the Property Valuers Profession Act, No. 47 of 2000. Government Gazette, 426 (1822), pp. 1-38

South African Council for the Property Valuers Profession (2004). Code of Conduct for Registered Persons. [Online] Available: http://www.sacpvp.co.za/index.php/contact-us-107.html (Accessed 30 September 2012).

South African Institute of Valuers (2009). Constitution. [Online] Available: http://www.saiv.org.za/index. (Accessed 10 october 2012).

Sui Pheng, L. \& Tan, P.L. (1995). Ethical expectations in the Singapore real estate industry. Journal of Property Management, 13(4), pp.5-12.

The International Valuation Standards Council [Online] Available: http://www.ivsc.org (Accessed 13 November 2012).

Tseng, H., Duan, C., Tung, H. \& Kung, H. (2010). Modern business ethics research: concepts, theories, and relationships. Journal of Business Ethics, 91(4), 587-597.

Votano, J., Parham, M. \& Hall, L. (2004). Code of Conduct for registered persons, pp.1-3. [Online] Available: http://www.sacpvp.co.za/ (Accessed September 17, 2012).

Walt, A.J.V.D. (2010). Changes in attitudes towards business ethics held by past South African business management students. Masters dissertation. Pretoria: University of Pretoria, Gordon Institute of Business Science.

Zikmund W.G., Babib B.J., Carr J.C. \& Griffin, M. (2010). Business Research Methods, $8^{\text {th }}$ edition. SouthWestern: Cengage Learning. 